\title{
Expression of Survivin in Squamous Cell Lung Cancer and Its Correlation with Prognosis
}

\author{
Burcu Y. TASKOYLU', Gamze G. DOGU², Aydın DEMIRAY3, Hakan AKCA³, \\ Ferda BIR ${ }^{4}$, A. Gokcen DEMIRAY ${ }^{1}$, Arzu YAREN ${ }^{2}$, Ahmet ERGIN ${ }^{5}$ \\ ${ }^{1}$ Denizli State Hospital, Medical Oncology Clinic \\ ${ }^{2}$ University of Pamukkale Faculty of Medicine, Department of Internal Medicine \\ ${ }^{3}$ University of Pamukkale Faculty of Medicine, Department of Medical Biology \\ ${ }^{4}$ University of Pamukkale Faculty of Medicine, Department of Pathology \\ ${ }^{5}$ University of Pamukkale Faculty of Medicine, Department of Public Health, Denizli, TURKEY
}

\begin{abstract}
There are outstanding studies on the importance of survivin and inhibition of apoptosis in many cancers, including lung. Evaluation of the relationship between survivin expression in lung cancer and prognosis is the aim of this study. A total of 50 patients with a diagnosis of squamous cell lung carcinoma were included in this study. Survivin levels that were obtained with IHC (immunohistochemical) and RT-PCR (reverse transcription-polymerase chain reaction) methods from the tumor and metastatic lymph node tissues embedded in paraffin blocks were evaluated along with clinical parameters. The median age of the patients was 60 years (range 54-69). All patients were male and all of them were smokers. The mean duration of follow-up and disease-free survival was $42.08 \pm 22.46$ months and 40.62 \pm 22.46 months, respectively. Significant associations were found among survivin levels in metastatic lymph nodes and duration of smoking ( $\mathrm{HHC}$ and $\mathrm{RT}-\mathrm{PCR})$, angiolymphatic invasion $(\mathrm{IHC})$, the number of mitosis (RT-PCR) $(p=0.05$ and $p=0.05, p<$ $0.001, p=0.02$, respectively). Survivin showed statistically significant associations with angiolymphatic invasion and stage in multivariate analysis $(p<0.001, p=0.04$, respectively). An association was not found between survivin levels in tumor and lymph nodes and survival. Higher survivin levels in lymph nodes detected by $\mathrm{HHC}$ was associated with shorter survival but that didn't reach statistical significance $(65.22 \pm 5.16$ vs $42.33 \pm 11.97, p=0.72)$. Further larger studies done with larger numbers of patients are required in order to evaluate its effects in our society.
\end{abstract}

Keywords: Survivin, Squamous cell lung cancer, Survival

ÖZET

\section{Skuamoz Hücreli Akciğer Kanserinde Survivin Ekspresyonu ve Prognostik Korelasyonu}

Akciğer kanseri de dahil olmak üzere birçok kanserde apopitozis inhibisyonu ve survivinin önemine değinen önemli çalışmalar bulunmaktadır. Bu çalışmanın amacı akciğer kanserinde survivin ekspresyonu ile prognoz ilişkisini değerlendirmektir. Skuamoz hücreli akciğer kanseri tanıı toplam 50 hasta çalışmaya alındı. Tümör ve metastatik lenf nodlarında survivin düzeyi IHK (Immunhistokimya) ve RT-PCR (reverz transkripsiyon-polimeraz zincir reaksiyonu) yöntemleri ve klinik parametrelerle beraber değerlendirildi. Hastaların median yaş değeri 60 yıl (sınılar 54-69) idi. Hastaların hepsi erkekti ve hepsi sigara içicisiydiler. Ortalama takip süresi $42.08 \pm 22.46$ ay, hastalıksız sağkalım süresi ise $40.62 \pm 22.46$ ay olarak hesaplandı. Metastatik lenf nodundaki survivin düzeyiyle, sigara içme süresi (iHK ve RT-PCR), anjiyolenfatik invazyon varlığı (lHK) ve mitoz sayısı (RT-PCR) arasında anlamlı ilişki saptandı (sırasıyla $p=0.05, p=0.05, p<$ $0.001, p=0.02$ ). Mutivariet analizde survivin ile anjiyolenfatik invazyon varlığı ve evre arasında anlamlı ilişki bulundu (sırasıyla, $p<0.001$, $p=0.04$ ). Tümör ve lenf nodundaki survivin seviyesi ile sağkalım arasında anlamlı ilişki bulunamadı. Lenf nodunda IHK ile saptanan yüksek survivin düzeylerinde sağkalım daha kısa olmakla beraber istatistiksel olarak anlamlılık saptanmadı. Toplumumuzda survivinin prognostik ve prediktif önemini belirlemek için daha fazla hasta sayısıyla yapılacak daha kapsamlı çalışmalara intiyaç vardır.

Anahtar Kelimeler: Survivin, Skuamoz hücreli akciğer kanseri, Sağkalım 


\section{INTRODUCTION}

Lung cancer consists $12 \%$ of all cases of cancer globally. It occupies the second place among causes of cancer-related deaths in males and females. ${ }^{1,2}$ Smoking is the most important etiologic factor in the development of lung cancer. The risk of lung cancer is 20 times higher in smokers in comparison to non-smokers. Age to start smoking, total duration of smoking, total number of cigarettes smoked, are all effective on the risk. ${ }^{3}$

Recently, some targets related to adenocarcinoma subtype were detected and drugs targeting them were developed, but for squamous cell carcinoma until now there is no such type of specific target. The first line of therapy for this histological type is chemotherapy. Studies on determination of biomarkers for predicting prognosis and response to chemotherapy have increased recently.

Apoptosis is a process which is important in both carcinogenesis and cancer treatment. ${ }^{4-6}$ There are outstanding studies on the importance of survivin and inhibition of apoptosis in many cancers, including breast, lung, esophagus, stomach, headneck, and cervix..$^{7-11}$

Survivin is a protein which is made up of 142 amino acids of $16.5 \mathrm{kD}$, and is an apoptosis inhibitor. It is the smallest member of IAP (inhibitor apoptotic protein) family in mammals. ${ }^{12}$ According to some studies surviving may act as a target for cancer treatment and as a prognostic marker. ${ }^{13-14}$

There is no data on the literature evaluating the correlation between survivin in squamous cell subtype and clinicopathological parameters and survival. There are recent notable studies evaluating the relationship between especially response to chemotherapy, EGFR resistance and surviving. ${ }^{15-18}$

In this study, the relationship between survivin in both tumor and metastatic lymph nodes and clinicopathological parameters and survival in patients with squamous cell non-small cell lung cancer, which is more frequently seen in our country were evaluated. The study was approved by the Ethics Committee of Pamukkale University and scientific investigation project.

\section{PATIENTS AND METHODS}

A total of 50 patients with squamous cell lung car- cinoma, stages between 1-3, who had undergone pneumonectomy, lobectomy, or wedge resection, who had not received neoadjuvant chemotherapy or radiotherapy, treated and followed-up by the $\mathrm{Pa}$ mukkale University Medical School Department of Medical Oncology between the years 2005-2013 were examined retrospectively. The demographic data of the patients, tumor types, chemotherapies received were extracted from the patient files. The patients were detected from the patient follow-up files of Outpatient Clinics of Medical Oncology, and the stages, duration of survival were examined statistically at the end of study.

Determination of survivin expression with IHC method: The diagnosis of lung carcinoma, tumor differentiation in the histological sections of resection materials, and the presence of metastatic lymph node in lymph node dissection materials were reexamined and re-evaluated. The samples that best reflected the tumor tissue were selected. Five 3 micron sections were taken for the purpose of survivin antibody examination to positive - charged glasses from selected paraffin blocks for each case. The tissue samples were left at $50^{\circ} \mathrm{C}$ for one night in the incubator for deparaffination. They were later dyed automatically with the help of VENTANA, Benchmark LT device. In sections dyed automatically, 1/200 diluted survivin antibody (Anti-BIRC5 policlonal rabbit antibody, BiOSs, Woburn, USA) was used and the targeted proteins were visualized. The duration of incubation with antibodies was 36 minutes for survivin. After which, it was held in $70 \%$ alcohol for 2 minutes, in $80 \%$ alcohol for 2 minutes, in $95 \%$ alcohol for 2 minutes and absolute alcohol for 2 minutes, sequentially. The sections were dried in the air and held in Xylene for 15 minutes, and closed with entellan.

Survivin expression was determined in the cytoplasm. Cytoplasmic staining was considered positive for survivin, and other staining were considered negative in the evaluation. Cytoplasmic survivin staining was recorded in between $0-100$ $\%$ according to diffusiveness. Staining of 50\% and more of the cells was considered as an increased survivin expression (Picture 1).

Determination of survivin expression with RT-PCR method: Both tumor tissues of patients and also 10 $\mu \mathrm{m}$ sections of lymph nodes in terms of distant or- 


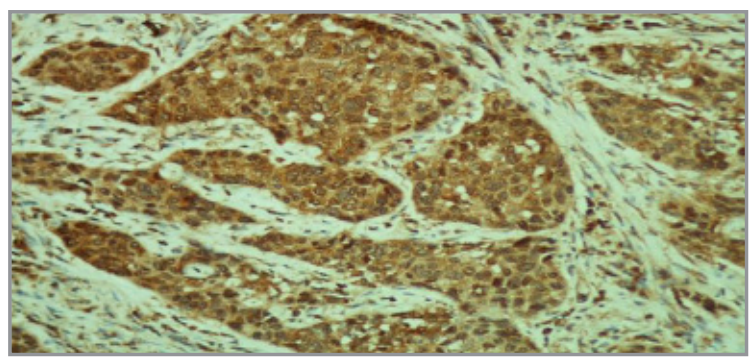

Picture 1. Higher expression level of survivin in poorly differentiated tumors

gan metastasis were transported to sterile ependorf tubes. These were incubated at $56^{\circ} \mathrm{C}$ for $20 \mathrm{~min}-$ utes with xylene in order to remove paraffin from these tissues. Afterwards, paraffin was removed by centrifugation at $14000 \mathrm{xg}$ for 2 minutes. After this procedure, xylene was removed with use of $96 \%$ absolute alcohol. After centrifugation at 14000 $\mathrm{xg}$ for 2 minutes, the supernatant was removed. The pellet was incubated at $56^{\circ} \mathrm{C}$ for 15 minutes for evaporation of alcohol from the environment. Then, RNA was isolated with use of qiagen FFPE isolation (kat:73504 Germany) kit. The RNA thus obtained was measured with a nanodrop and was stored at $-80^{\circ} \mathrm{C}$. After total RNA levels of all patients were obtained, total RNAs were turned into cDNA with the help of qiagen cDNA (Kat:679923 France) synthesis kit. The protocol was as follows; $5 \mathrm{x}$ tampon $5 \mu \mathrm{l}$, dNTP $100 \mathrm{nM}$, random nanomer 5,2 $\mu 1$, reverse transcriptase $1 \mu 1$, DTT 1,25 $\mu 1$, RNAse inhibitor $0,5 \mu 1$, sample $10 \mu \mathrm{l}$ reaction complex were prepared. cDNA was obtained after incubations at $65^{\circ} \mathrm{C}$ for 5 minutes, on ice for 5 minutes, at $25^{\circ} \mathrm{C}$ for 10 minutes, at $50^{\circ} \mathrm{C}$ for 60 minutes and at $85^{\circ} \mathrm{C}$ for 5 minutes and measured at nanodrop. For investigation of real-time PCR with obtained cDNA, survivin (Roche Applied Science Basel Switzerland), caspase 9 (Roche Applied Science Basel Switzerland) and beta actin (Roche Applied Science Basel Switzerland) gene expressions were examined. The reaction conditions were as follows: 10 minutes at $95^{\circ} \mathrm{C}$ for 1 cycle, at $95^{\circ} \mathrm{C}$ for 10 seconds, at $60^{\circ} \mathrm{C}$ for 30 seconds, at $72^{\circ} \mathrm{C}$ for 1 second (reading) for 45 cycles and cooling was done at $40^{\circ} \mathrm{C}$ for 30 seconds. Calculations were done with the ratio of obtained beta actin cycle number with the other target gene (delta ct). Median values were determined from results obtained

\begin{tabular}{|c|c|c|}
\hline Characteristics & Patient, n (\%) & Mean \pm SD \\
\hline Age (year) & - & $61.94 \pm 7.61$ \\
\hline \multicolumn{3}{|l|}{ Gender } \\
\hline Male & $50(100)$ & \\
\hline Female & $0(0)$ & \\
\hline \multicolumn{3}{|l|}{ Smoking } \\
\hline Yes & $50(100)$ & \\
\hline No & $0(0)$ & \\
\hline Smoking time (month) & - & $29.60 \pm 8.91$ \\
\hline \multicolumn{3}{|l|}{ Operation } \\
\hline Lobectomy & $29(58)$ & \\
\hline Pneumonectomy & $20(40)$ & \\
\hline Wedge resection & $1(2)$ & \\
\hline \multicolumn{3}{|l|}{ Lymph node metastasis } \\
\hline Yes & $21(42)$ & \\
\hline No & $29(58)$ & \\
\hline \multicolumn{3}{|l|}{ Stage } \\
\hline $1-2$ & $45(90)$ & \\
\hline 3 & $5(10)$ & \\
\hline \multicolumn{3}{|l|}{ Tumor localization } \\
\hline Central & $33(66)$ & \\
\hline Peripheral & $17(34)$ & \\
\hline \multicolumn{3}{|l|}{ Tumor differentiation } \\
\hline Poor & $12(24)$ & \\
\hline Moderate-well & $38(76)$ & \\
\hline Tumor mitotic count & - & $7.86 \pm 3.05$ \\
\hline \multicolumn{3}{|l|}{ Angiolymphatic invasion } \\
\hline Yes & $28(56)$ & \\
\hline No & $22(44)$ & \\
\hline \multicolumn{3}{|l|}{ Adjuvant chemotherapy } \\
\hline Yes & $22(44)$ & \\
\hline No & $28(56)$ & \\
\hline \multicolumn{3}{|l|}{ Adjuvan radiotherapy } \\
\hline Yes & $3(6)$ & \\
\hline No & $47(94)$ & \\
\hline \multicolumn{3}{|l|}{ Metastasis } \\
\hline Yes & $9(18)$ & \\
\hline No & $41(82)$ & \\
\hline $\begin{array}{l}\text { Progression-free survival } \\
\text { (month) }\end{array}$ & - & $40.62 \pm 22.46$ \\
\hline Overall survival (month) & - & $42.08 \pm 20.68$ \\
\hline
\end{tabular}

from tumor and lymph nodes. Survivin values of 1.4 and more in the tumor, and 0.52 and over in the lymph node were considered as increased.

\section{Statistical Analysis}

SPSS version 17 was used in the statistical analysis. Descriptive statistics were presented as mean, standard deviation and percent. Significance of differences between the groups was evaluated 
International Journal of Hematology and Oncology

Table 2. Associations between survivin levels in metastatic lymph nodes and histopathological characteristics of the patients

\begin{tabular}{|c|c|c|c|c|c|c|}
\hline \multirow[b]{3}{*}{ Characteristics } & \multicolumn{6}{|c|}{ Level of survivin in metastatic lympnode } \\
\hline & & \multirow[b]{2}{*}{$\mathbf{n}$} & \multicolumn{2}{|c|}{ IHC } & \multicolumn{2}{|c|}{ RT-PCR } \\
\hline & & & Mean \pm SD & $\mathbf{p}$ & Mean \pm SD & $\mathbf{p}$ \\
\hline \multirow[t]{2}{*}{ Age (year) } & $<65$ & 32 & $19.44 \pm 32.80$ & 0.09 & $0.33 \pm 0.82$ & 0.70 \\
\hline & $>65$ & 18 & $37.03 \pm 42.67$ & & $0.44 \pm 0.96$ & \\
\hline \multirow[t]{2}{*}{ Smoking time } & $\leq 30$ pocket/year & 23 & $20.65 \pm 36.19$ & $0.05^{\star}$ & $0.12 \pm 0.43$ & $0.05^{\star}$ \\
\hline & $>30$ pocket/year & 27 & $39.25 \pm 41.68$ & & $0.58 \pm 1.07$ & \\
\hline \multirow[t]{2}{*}{ Mitotic count } & $\operatorname{Low}(\leq 7)$ & 26 & $30.57 \pm 39.65$ & 0.88 & $0.27 \pm 0.97$ & $0.02^{*}$ \\
\hline & High $(>7)$ & 24 & $30.83 \pm 41.16$ & & $0.48 \pm 0.74$ & \\
\hline \multirow[t]{3}{*}{ Operation } & Lobectomy & 29 & $22.06 \pm 37.35$ & 0.09 & $0.38 \pm 0.98$ & 0.73 \\
\hline & Pneumonectomy & 20 & $44.75 \pm 41.15$ & & $0.37 \pm 0.71$ & \\
\hline & Wedge resection & 1 & $1.00 \pm 0.00$ & & $1.00 \pm 0.00$ & \\
\hline \multirow[t]{2}{*}{ Stage } & 2 & 45 & $26.33 \pm 39.57$ & $0.03^{*}$ & $0.36 \pm 0.89$ & 0.28 \\
\hline & 3 & 5 & $70.00 \pm 14.14$ & & $0.50 \pm 0.68$ & \\
\hline \multirow[t]{2}{*}{ Tumor localization } & Peripheral & 17 & $29.24 \pm 40.11$ & 0.63 & $0.36 \pm 0.97$ & 0.32 \\
\hline & Central & 33 & $33.52 \pm 40.76$ & & $0.39 \pm 0.65$ & \\
\hline \multirow[t]{2}{*}{ Tumor differentiation } & Poor & 12 & $14.16 \pm 33.15$ & 0.09 & $0.31 \pm 0.56$ & 0.72 \\
\hline & Moderate-well & 38 & $35.92 \pm 40.89$ & & $0.39 \pm 0.95$ & \\
\hline \multirow[t]{2}{*}{ Angiolymphatic invasion } & Yes & 28 & $50.17 \pm 41.91$ & $<0.001^{*}$ & $0.43 \pm 0.88$ & 0.36 \\
\hline & No & 22 & $5.90 \pm 17.90$ & & $0.30 \pm 0.86$ & \\
\hline \multirow[t]{2}{*}{ Metastasis } & Yes & 9 & $33.53 \pm 41.20$ & 0.47 & $0.41 \pm 0.91$ & 0.65 \\
\hline & No & 41 & $17.77 \pm 32.70$ & & $0.20 \pm 0.62$ & \\
\hline
\end{tabular}

with Mann-Whitney U test. Associations between quantitative data were determined with the help of Spearman correlation test. Progression-free and overall survival was calculated with KaplanMeier. Log-rank was used for statistical significance and $\mathrm{p}<0.05$ was considered as statistically significant. In evaluation of tumor and lymph node survivin levels in multivariate analysis, linear regression was used and cox regression analysis was used for evaluation of survival duration.

\section{RESULTS}

The median age of 50 patients included in this study was 60 years (range, 54-69). All of the patients were males and all had a history of past smoking. Twenty-two (44\%) patients had received adjuvant chemotherapy, 3 patients $(6 \%)$ had adjuvant radiotherapy. Twenty nine patients had undergone (58\%) lobectomy, 20 had undergone pneumonectomy (40\%), 1 patient (2\%) had undergone wedge resection. In histopathological examination, 12 of the patients had poor differentiated morphology, whereas 38 showed moderatewell differentiation. The tumor diameter was $1 \mathrm{~cm}$ at its smallest point, and $10 \mathrm{~cm}$ at its largest, with a mean value of $4.01 \pm 2.09 \mathrm{~cm}$. The tumor had a central location in $33(66 \%)$ patients, and peripheral location in 17 (34\%) patients. In histopathological examination, the mean number of mitosis in the tumor was 7 (range, 4-10). Of the patients, $28(56.0 \%)$ had angiolymphatic invasion, and 21 (42\%) had lymph node metastasis. Forty-five patients (90\%) were at stage 1 and 2, 5 patients $(10 \%)$ were at stage 3 . The mean duration of follow-up was $42.08 \pm 20.68$ months in 50 patients. The mean disease-free duration of survival of the patients was $40.62 \pm 22.46$ months, and the general duration of survival was $42.08 \pm 20.68$ months. The histopathological characteristics of the patients are presented in Table 1. The mean survivin level in the tumor was $74.70 \pm 27.30$ with IHC method; and 


\begin{tabular}{|c|c|c|}
\hline & Mean \pm SD & p \\
\hline \multicolumn{3}{|l|}{ Age (year) } \\
\hline$\leq 65$ & $62.23 \pm 4.27$ & \multirow[t]{2}{*}{0.78} \\
\hline$>65$ & $63.58 \pm 5.46$ & \\
\hline \multicolumn{3}{|c|}{ Lymph node metastasis } \\
\hline No & $63.66 \pm 5.10$ & \multirow[t]{2}{*}{0.79} \\
\hline Yes & $61.05 \pm 4.65$ & \\
\hline \multicolumn{3}{|l|}{ Stage } \\
\hline $1-2$ & $62.79 \pm 3.62$ & \multirow[t]{2}{*}{0.97} \\
\hline 3 & $60.00 \pm 10.73$ & \\
\hline \multicolumn{3}{|c|}{ Angiolymphatic invasion } \\
\hline No & $64.33 \pm 4.33$ & \multirow[t]{2}{*}{0.59} \\
\hline Yes & $59.43 \pm 5.67$ & \\
\hline \multicolumn{3}{|c|}{ Tumor differentiation } \\
\hline Poor & $62.15 \pm 4.01$ & \multirow[t]{2}{*}{0.73} \\
\hline Moderate-well & $62.25 \pm 6.29$ & \\
\hline \multicolumn{3}{|c|}{ Adjuvant Chemotherapy } \\
\hline No & $50.45 \pm 4.78$ & \multirow[t]{2}{*}{0.01} \\
\hline Yes & $72.52 \pm 2.39$ & \\
\hline \multicolumn{3}{|l|}{ Metastasis } \\
\hline No & $73.46 \pm 1.51$ & \multirow[t]{2}{*}{$p<0.001$} \\
\hline Yes & $18.33 \pm 2.36$ & \\
\hline \multicolumn{3}{|l|}{ Smoking time } \\
\hline$<30$ pocket yea & $66.98 \pm 3.34$ & \multirow[t]{2}{*}{0.02} \\
\hline$\geq 30$ pocket yea & $47.26 \pm 8.10$ & \\
\hline \multicolumn{3}{|c|}{ Level of survivin in tumor cell by $I \mathrm{HC}$} \\
\hline Low $(<\% 50)$ & $60.97 \pm 3.49$ & \multirow[t]{2}{*}{0.73} \\
\hline High (>\%50) & $59.62 \pm 9.41$ & \\
\hline \multicolumn{3}{|c|}{ Level of survivin in tumor cell by RT-PCR } \\
\hline Low $(\leq 1.39)$ & $62.04 \pm 4.52$ & \multirow[t]{2}{*}{0,62} \\
\hline High (>1.39) & $61.26 \pm 4.90$ & \\
\hline \multicolumn{3}{|c|}{ Level of survivin in metastatic lympnode by $\mathrm{IHC}$} \\
\hline Low $(<\% 50)$ & $65.22 \pm 5.16$ & \multirow[t]{2}{*}{0.72} \\
\hline High (>\%50) & $42.33 \pm 11.97$ & \\
\hline \multicolumn{3}{|l|}{$\begin{array}{l}\text { Level of survivin } \\
\text { PCR }\end{array}$} \\
\hline Low $(\leq 0.51)$ & $68.50 \pm 5.21$ & \multirow[t]{2}{*}{0.32} \\
\hline High $(>0.51)$ & $61.07 \pm 4.06$ & \\
\hline
\end{tabular}

$30.70 \pm 39.9$ in the lymph node. According to extensiveness of cytoplasmic survivin staining, values between 0-100\% were found. Staining of 50\% and more of the cells was considered as evidence of increased survivin expression. As there are no studies in the medical literature examining survivin levels in metastatic lymph nodes, survivin in lymph nodes was considered as in the tumor. The mean survivin value in the tumor was found to be $2.44 \pm 2.94$ with PCR method, and $0.37 \pm 0.86$ in the lymph node. For the survivin values determined with PCR method, threshold value for the tumor was 1.39 with ROC analysis and it was 0.51 for the lymph node. No correlations were found between survivin levels determined with IHC and PCR methods in the tumor. Also, there were no associations between survivin levels determined with IHC and PCR methods in the lymph nodes ( $\mathrm{p}>0.05$ ). As it is shown in Table 2, significant associations were found between survivin levels in metastatic lymph nodes and the duration of smoking (IHC and RT-PCR), angiolymphatic invasion (IHC) and the number of mitosis (RT-PCR) $(\mathrm{p}=0.05$ and $\mathrm{p}=$ $0.05, \mathrm{p}<0.001, \mathrm{p}=0.02$, respectively). There was a significant association between angiolymphatic invasion and stage with survivin levels in multivariate analysis $(\mathrm{p}<0.001, \mathrm{p}=0.04$, respectively). In survivin levels which were found to be increased in the lymph node with IHC, OS was shorter but it did not reach statistical significance $(65.22 \pm 5.16$ vs $42.33 \pm 11.97, \mathrm{p}=0.72$ ). An association was not found between survivin levels in the tumor and lymph node and OS (Figure 1 and 2). Only lymph node metastasis were significantly correlated with OS in multivariate analysis $(\mathrm{p}=0.001)$ (Tables 3,4$)$.

\begin{tabular}{|lllll|}
\hline \multicolumn{4}{|l|}{ Table 4. Associations between survivin levels in the tumor and lymph node and OS in multivariate analysis } \\
\hline & Beta & $\mathbf{9 5 \%} \mathbf{C l}$ & & p value \\
\hline Adjuvant chemotherapy & 6.03 & 0.45 & 80.93 & 0.17 \\
Metastasis & 112.78 & 7.35 & 1725.53 & $0.001^{*}$ \\
Smoking time & 0.83 & 0.14 & 4.78 & 0.84 \\
Level of survivin in tumor cells by IHC & 1.04 & 0.10 & 10.38 & 0.96 \\
Level of survivin in metastatic lympnode by IHC & 3.04 & 0.16 & 55.60 & 0.45 \\
\hline * $p$ values are obtained by lineer regression analysis. $p<0.05$ is accepted to be statistically significant & \\
\hline
\end{tabular}




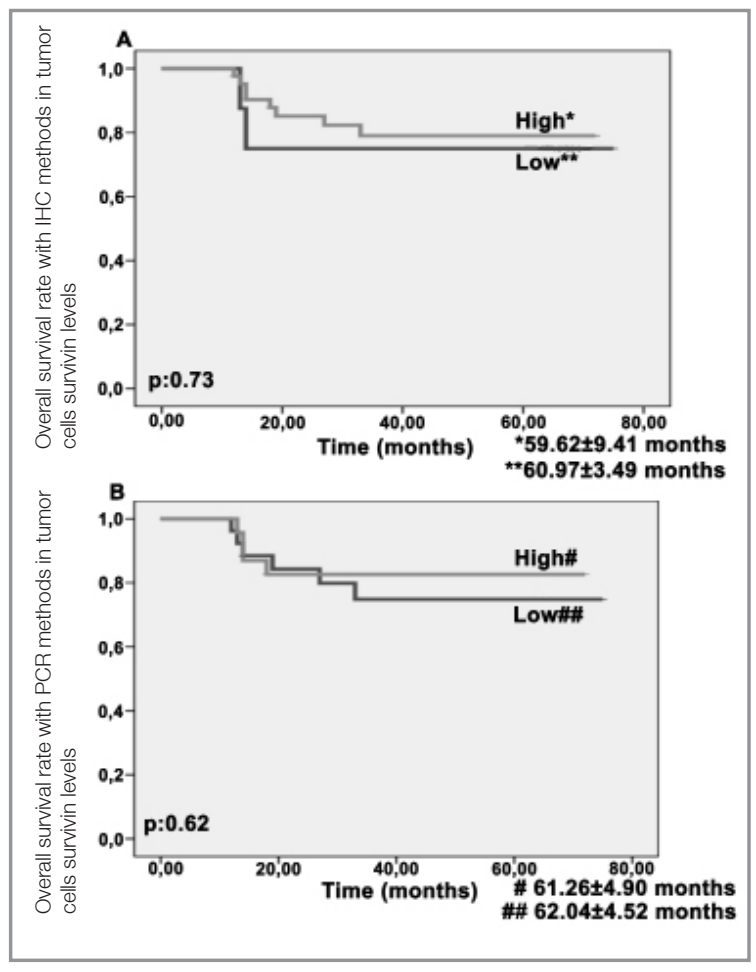

Figure 1. (A) Overall survival rate with $I H C$ methods in tumor cells survivin levels; (B) Overall survival rate with PCR methods in tumor cells survivin levels

\section{DISCUSSION}

Survivin is expressed in embrionic cells and malignant cells, but it is not expressed in mature-differentiated cells. ${ }^{19}$ The relationship between survivin, which is an anti-apoptotic protein, and a number of cancers were documented. It may show different functions according to the locations. Survivin, which is a member of IAP family inhibits apoptosis by inhibiting caspase 3 and $7 .{ }^{20}$

When the level of expression is evaluated, more survivin expression was reported in the study by Falleni et al. in patients with squamous cell lung cancer in comparison with adenocarcinoma and large cell subtypes. ${ }^{21}$ In the studies by Sun, Huang no differences in expression were found between histological subtypes. ${ }^{22,23}$

Its prognostic value was assessed but clinicopathological correlations were not examined in any studies. ${ }^{24-30}$ In terms of data on its prognostic significance, there are studies in which it was found to be a marker of poor prognosis, while there are other studies which have found the contrary. ${ }^{25-27}$ Also,

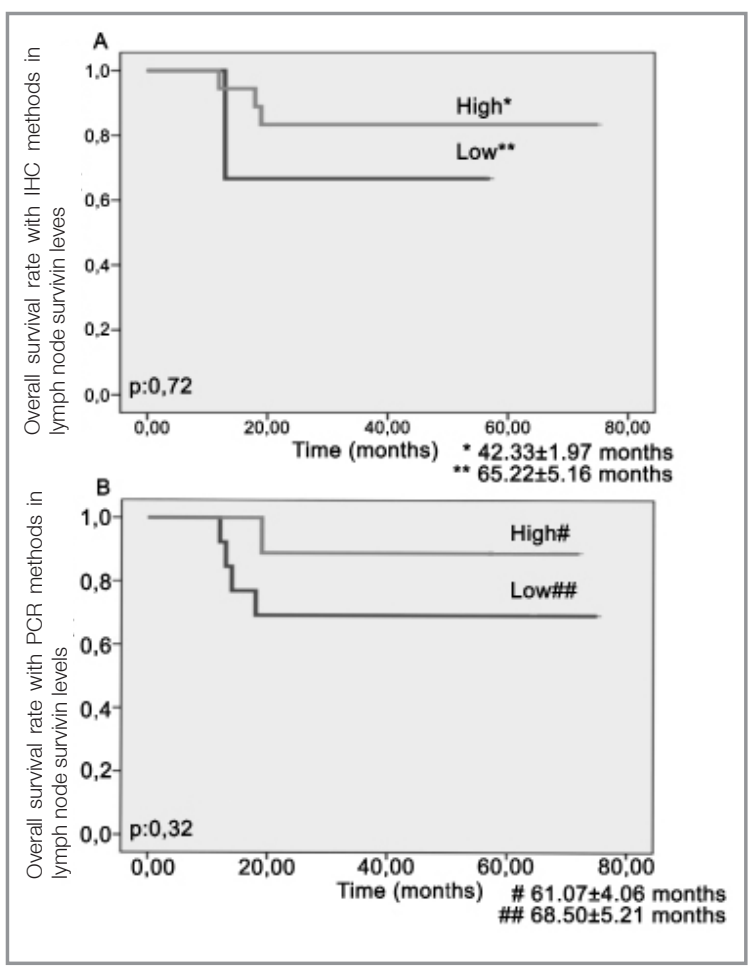

Figure 2. (A) Overall survival rate with $\mathrm{HC}$ methods in lymph node survivin leves; (B) Overall survival rate with PCR methods in lymph node survivin levels

there are no studies in the literature investigating the relationship between metastatic lymph node and clinical characteristics and survival in squamous cell subtype. Small groups of patients with squamous cell and adenocarcinoma were examined in these studies. A total of 225 patients with adenocarcinoma and 148 patients with squamous cell carcinoma were evaluated in the study by Sun et al, which may be considered as the most extensive investigation, and prognostic significance was not found in patients with squamous cell carcinoma. ${ }^{22}$ There are no studies in which metastasis was investigated along with the tumor tissue. According to our study, it may be stated that it is one of the factors that contribute to progression. In terms of survival, the inverse relationship between survivin levels and survival in lymph node metastasis may provide an important clue for us, although it did not reach statistical significance. Along with data showing that survivin m-RNA levels may be effective in predicting response to anti-EGFR agents, there is also data that it may be effective in over- 
coming resistance to therapy with tyrosine kinase inhibitors. ${ }^{15,31}$

It is also not clear how survivin levels should be evaluated. In a literature evaluation, values between 10-50\% were found to be reported in studies with IHC method. ${ }^{32}$ Furthermore, the threshold value with PCR method in the literature is different in each study. ${ }^{33,34} \mathrm{~A}$ correlation between IHC and RT-PCR was not found in our study. But a conclusion may be reached with large-scale studies evaluating both methods together.

When racial differences are considered, it is hard to reach a conclusion, as there are no studies evaluating the relationship between survivin and squamous cell lung cancer in our society. Another important problem preventing conclusions in other racial groups is the larger number of studies on Asian populations.

The limitations of our study include the absence of control groups, the small sample size. Limitations in labour and economic conditions prevented us to overcome these limitations.

\section{CONCLUSION}

Survivin expression increases during the metastatic process and shows a negative correlation with OS. Higher survivin levels in lymph nodes detected by IHC were associated with shorter survival. An association was not found between survivin levels in tumor and lymph nodes and survival. Further larger studies done with larger numbers of patients are required in order to evaluate its effects in our society. Due to heterogeneity in the studies, more homogenous data are needed to assess survivin in squamous lung cancer. Also, combinations with targeted agents and immunotherapy may contribute in the prevention of resistance, and we believe that detailed investigations on this issue in the future may provide an effective strategy in increasing the probability of cure.

\section{Acknowledgements:}

The authors would like to thank so much all of the participants for their support.

\section{REFERENCES}

1. van Meerbeeck JP, Fennell DA, De Ruysscher DK. Small-cell lung cancer. Lancet 378: 1741-1755, 2011.

2. Siegel RL, Miller KD, Jemal A. Cancer statistics, 2016. CA Cancer J Clin 66: 7-30, 2016.

3. Khuder SA. Effect of cigarette smoking on major histological types of lung cancer: a meta-analysis. Lung Cancer 31: 139148, 2001.

4. Wong RS. Apoptosis in cancer: from pathogenesis to treatment. J Exp Clin Cancer Res 30: 87, 2011.

5. Fesik SW. Promoting apoptosis as a strategy for cancer drug discovery. Nat Rev Cancer 5: 876-885, 2005.

6. Fulda S, Debatin KM. Extrinsic versus intrinsic apoptosis pathways in anticancer chemotherapy. Oncogene 25: 47984811, 2006.

7. Lo Muzio L, Pannone G, Staibano S, et al. Survivin expression in oral squamous cell carcinoma. Br J Cancer 89: 22442248, 2003

8. Ikeguchi M, Kaibara N. Survivin messenger RNA expression is a good prognostic biomarker for oesophageal carcinoma. Br J Cancer 87: 883-887, 2002.

9. Tsuburaya A, Noguchi Y, Yoshikawa T, et al. An anti-apoptosis gene, survivin and telomerase expression in gastric cancer. Hepatogastroenterology 49: 1150-1152, 2002.

10. Guney N, Soydine HO, Derin D, et al. Serum and urine survivin levels in breast cancer. Med Oncol 23: 335-339, 2006.

11. Zannoni GF, Petrillo M, Vellone VG, et al. Survivin protein as predictor of pathologic response in patients with locally advanced cervical cancer treated with chemoradiation followed by radical surgery. Hum Pathol 45: 1872-1878, 2014.

12. Altieri DC. Validating survivin as a cancer therapeutic target. Nat Rev Cancer 3: 46-54, 2003.

13. Chen X, Duan N, Zhang C, Zhang W. Survivin and Tumorigenesis: Molecular Mechanisms and Therapeutic Strategies. J Cancer 7: 314-323, 2016.

14. Chandele A, Prasad V, Jagtap JC, et al. Upregulation of survivin in G2/M cells and inhibition of caspasee 9 activity enhances resistance in staurosporine-induced apoptosis. Neoplasia 6: 29-40, 2004.

15. Shi WL, Li J, Bao QL, et al. Survivin mRNA expression in blood as a predictor of the response to EGFR-tyrosine kinase inhibitors and prognosis in patients with non-small cell lung cancer. Med Oncol 31: 893, 2014.

16. Du YJ, Li J, Zhu WF, et al. Survivin mRNA-circulating tumor cells predict treatment efficacy of chemotherapy and survival for advanced non-small cell lung cancer patients. Tumour Biol 35: 4499-4507, 2014. 
17. Wang S, Zhu L, Zuo W, et al. MicroRNA-mediated epigenetic targeting of Survivin significantly enhances the antitumor activity of paclitaxel against non-small cell lung cancer. Oncotarget 7: 37693-37713, 2016.

18. Lee SH, Lee JY, Jung CL, et al. A novel antagonist to the inhibitors of apoptosis (IAPs) potentiates cell death in EGFRoverexpressing non-small-cell lung cancer cells. Cell Death Dis 5: e1477, 2014. doi: 10.1038/cddis.2014.447

19. Duan $L, H u X$, Jin $Y$, et al. Survivin protein expression is involved in the progression of non-small cell lung cancer in Asians: a meta-analysis. BMC Cancer 16: 276, 2016. doi: 10.1186/s12885-016-2304-3.

20. Akyurek N, Memis L, Ekinci $O$, et al. Survivin expression in pre-invasive lesions and non-small cell lung carcinoma. Virchows Arch 449: 164-170, 2006.

21. Falleni $M$, Pellegrini $C$, Marchetti $A$, et al. Survivin gene expression in early stage non-small cell lung cancer. J Pathol 200: 620-626, 2003.

22. Sun $\mathrm{PL}$, Jin $\mathrm{Y}, \mathrm{Kim} H$, et al. Survivin expression is an independent poor prognostic marker in lung adenocarcinoma but not in squamous cell carcinoma. Virchows Arch 463: $427-$ 436, 2013.

23. Huang LN, Wang DS, Chen YQ, et al. Expression of survivin and patients survival in non-small cell lung cancer: a metaanalysis of the published studies. Mol Biol Rep 4: 917924, 2013.

24. Dai J, Jin G, Dong J, et al. Prognostic significance of survivin polymorphisms on non-small cell lung cancer survival. J Thorac Oncol 5: 1748-1754, 2010.

25. Rosato A, Menin C, Boldrin D, et al. Survivin expression impacts prognostically on NSCLC but not SCLC. Lung Cancer 79: 180-186, 2013.

26. Hu YM, Li J, Yu LC, et al. Survivin mRNA Level in Blood Predict the Efficacy of Neoadjuvant Chemotherapy in Patients with Stage IIIA-N2 Non-Small Cell Lung Cancer. Pathol Oncol Res 21: 257-265, 2015.

27. Kapellos G, Polonifi K, Farmakis D, et al. Overexpression of survivin levels in circulation and tissue samples of lung cancer patients. Anticancer Res 33: 3475-3480, 2013.

28. Zhang $L Q$, Wang J, Jiang F, et al. Prognostic value of survivin in patients with non-small cell lung carcinoma: a systematic review with meta-analysis. PLoS One 7: e34100, 2012. doi: 10.1371/journal.pone.0034100
29. Atikcan S, Unsal E, Demirag F, et al. Correlation between survivin expression and prognosis in non-small cell lung cancer. Respir Med 100: 2220-2226, 2006.

30. Hinnis AR, Luckett JC, Walker RA. Survivin is an independent predictor of short-term survival in poor prognostic breast cancer patients. Br J Cancer 96: 639-645, 2007.

31. Okamoto K, Okamoto I, Hatashita E, et al. Overcoming erlotinib resistance in EGFR mutation-positive non-small cell lung cancer cells by targeting survivin. Mol Cancer Ther 11: $204-$ 213, 2012.

32. Sui L, Dong $\mathrm{Y}$, Ohno M, et al. Survivin expression and its correlation with cell proliferation and prognosis in epithelial ovarian tumors. Int J Oncol 21: 315-320, 2002.

33. Dai CH, Li J, Shi SB, et al. Survivin and Smac gene expressions but not livin are predictors of prognosis in non-small cell lung cancer patients treated with adjuvant chemotherapy following surgery. Jpn J Clin Oncol 40: 327-335, 2010.

34. Yie Sm, Lou B, Ye Sr, et al. Clinical significance of detecting survivin-expressing circulating cancer cells in patients with non-small cell lung cancer. Lung Cancer 63: 284-290, 2009.

\section{Correspondence:}

Dr. Gamze Gokoz DOGU

Pamukkale Üniversitesi Tip Fakültesi

Tibbi Onkoloji Bilim Dali

Kınıklı

DENIZLI / TURKEY

Tel: (+90-258) 2962000 / 5142

Fax: (+90-258) 2962332

e-mail: ggd2882@gmail.com 